\title{
PENGARUH PELAYANAN AKADEMIK TERHADAP TINGKAT KEPUASAN MAHASISWA UNIVERSITAS BANTEN JAYA (UNBAJA)
}

\author{
Oleh :Khristina Sri Prihatin ${ }^{1}$,Yohana Selvia Dewi ${ }^{2}$ \\ Universitas Banten Jaya \\ Serang, Indonesia \\ khristinasriprihatin@unbaja.ac.id, yohanaselviadewi@unbaja.ac.id
}

\begin{abstract}
This research was conducted at University Banten Jaya (UNBAJA). The purpose of this research were: 1) to know how the quality of academic service. 2) to know how student satisfaction. 3) to know how the influence of academic service to the level of student satisfaction. In this research data collection technique was spreading questionnaires for 322 respondents(19,5\%) of 1.649 populations. The method used in this research was descriptive. The Data analysis included, validity test, reliability test, classical assumption test (residual normality, heteroscedasticity, linearity), correlation analysis, simple linear regression analysis, significance test ( $f$ test, $t$ test,coefficient of determination). The results were data analysis has been done obtained results where the academic services included into the category of "High Service Quality" (62,28\%). Meanwhile, the level of student satisfaction "Satisfied" category (0,81). And the influence of academic service to the level of student satisfaction was 0,678, it meant that the influence of Academic Service $(X)$ on Student Satisfaction Level was 67,80\% and 32,2\% was influenced by other variable. Thus it could be concluded that there was significant influence between the academic service on the level of student satisfaction.
\end{abstract}

Keyword: service and satisfaction

\section{PENDAHULUAN}

Pendidikan merupakan usaha sadar yang dilakukan untuk meningkatkan potensi sumber daya manusia (SDM) melalui kegiatan belajar mengajar. Pendidikan dapat dilakukan dalam organisasi formal yang memberikan pengajaran terhadap peserta didik. Salah satu organisasi formal dalam pendidikan yaitu perguruan tinggi. Dalam Peraturan pemerintah No. 30 Tahun 1990 tentang tujuan perguruan tinggi adalah menyiapkan peserta didik menjadi anggota masyarakat yang memiliki kemampuan akademik dan atau profesional yang dapat menerapkan, mengembangkan dan menyebarluaskan ilmu pengetahuan dan kesenian serta menyumbangkan untuk meningkatkan taraf kehidupan masyarakat dan memperkaya kehidupan nasional. Dengan tujuan tersebut, perguruan tinggi merupakan wadah atau penampung bagi para siswa yang ingin melanjutkan studinya ke tingkat yang lebih tinggi. Namun, perguruan tinggi bukanlah sekedar lembaga pendidikan saja, melainkan juga sebagai lembaga yang menjembatani antara mahasiswa (anak didik) dengan masyarakat sekitar, agar 
ilmu yang didapatkan di perguruan tinggi bisa bermanfaat tak hanya bagi mereka sendiri, tetapi juga bermanfaat bagi orang lain. Perguruan tinggi adalah satuan pendidikan penyelenggara pendidikan tinggi. Peserta didik perguruan tinggi disebut mahasiswa, sedangkan tenaga pendidik perguruan tinggi disebut dosen.

Salah satu bentuk pelayanan sebuah perguruan tinggi adalah pelayanan administrasi akademik. Mahasiswa merupakan pelanggan atau konsumen bagi institusi pendidikan tinggi. Institusi sudah seharusnya dapat menjamin kepuasan mahasiswa, tidak hanya dalam proses belajar mengajar, tetapi mencakup pula dalam pelayanan administrasinya. Pelayanan administrasi akademik merupakan bagian yang tidak terpisahkan dari seluruh kegiatan pendidikan disetiap perguruan tinggi. Pelayanan administrasi akademik sangat penting dalam menunjang kelancaran studi mahasiswa selama di perguruan tinggi. Peran pelayanan administrasi akademik menjadi hal yang perlu mendapatkan perhatian dari seluruh komponen yang terlibat dalam pengembangan perguruan tinggi. Proses administrasi akademik merupakan bagian yang paling banyak bersentuhan dengan mahasiswa, sehingga yang terpikir pertama kali oleh mahasiswa ketika ditanya bagaimana kualitas pelayanan di sebuah perguruan tinggi, maka yang dinilainya adalah pelayanan administrasi akademik, meskipun beberapa aspek sudah terkomputerisasi dan sudah online, namun pelayanan secara manual tetap diperlukan, sebagai contoh masalah legalisasi, surat menyurat, dan sebagainya.

Universitas Banten Jaya (UNBAJA) merupakan salah satu perguruan tinggi swasta yang terletak di Kota Serang, Provinsi Banten. Perguruan tinggi dengan 3 (tiga) fakultas dalam program pendidikan strata satu (S1) yang terdiri dari Fakultas Ilmu Komputer (FILKOM) dengan program studi Sistem Informatika (SI) dan Teknik Informatika (TI), Fakultas Teknik (FT) dengan program studi Teknik Sipil, Teknik Industri, dan Teknik Lingkungan, Fakultas Keguruan dan Ilmu Pendidikan (FKIP) dengan program studi Pendidikan Bahasa Inggris (PBI), Pendidikan Pancasila dan Kewarganegaraan (PKN) dan Pendidikan Akuntansi (PAK), serta melayani program pendidikan diploma III (D3) dengan program studi Teknik Informatika, Manajemen Informatika dan Komputer Akuntansi. Kesulitan yang sering terjadi pada bagian internal 
perguruan tinggi adalah banyaknya pengolahan data yang memerlukan pengolahan dalam waktu yang relatif singkat. Sebagai contoh antara pengolahan data mahasiswa yang mengambil mata kuliah dan kelas yang dengan pengajar dosen. Pada uraian diatas akan di dapat data transaksi berupa, data absensi, data mata kuliah, data transkrip nilai, data jadwal ujian, data biaya pembayaran (status pembayaran mahasiswa), data dosen beserta atribut data gaji yang merupakan bagian dari sistem keuangan yang diterapkan pada sisi keuangan. Maka dalam setiap perguruan tinggi terdapat bagian akademik yang akan bertugas untuk mengurus segala keperluan seperti yang dijelaskan di atas, sistem informasi akademik sangat membantu dalam pengelolaan data nilai mahasiswa, mata kuliah, data staf pengajar (dosen) serta administrasi fakultas/jurusan yang sifatnya masih manual untuk dikerjakan dengan bantuan software agar mampu mengefektifkan waktu dan menekan biaya operasional. Bagian administrasi akademik Fakultas langsung berhadapan dengan mahasiswa, sehingga layanan admininstrasi akademik perlu mendapatkan perhatian yang lebih agar dapat memberikan kepuasan yang optimal bagi mahasiswa.

Namun demikian sampai sekarang masih sering diketahui adanyakeluhankeluhan dari para mahasiswa. Pelayanan akademik yang dikeluhkan oleh sebagian besar mahasiswa terkait ketidaksesuaian nilai mahasiswa pada sistem akademik, intensitas keluarnya nilai perolehan akhir mahasiswa yang seringkali tidak tepat waktu, bimbingan/konsultasi akademik yang tidak memuaskan, sulitnya mendapatkan informasi terkait beasiswa, rendahnya fasilitas yang mendukung proses perkuliahan seperti LCD, spidol, penghapus whiteboard dan fasilitas lainnya yang kurang memadai, serta terjadinya pelayanan akademik di luar sistem administrasi yang kurang baik seperti masih adanya dosen yang seringkali tidak menunaikan tugasnya seperti memberikan materi tentang mata kuliah yang terkait, seringkali datang terlambat, bahkan terdapat dosen yang jarang sekali hadir untuk memberikan pembelajaran.

Keberhasilan fakultas sebagai unit kerja dalam perguruan tinggi sebagai lembaga pendidikan sangat ditentukan oleh mutu pelayanan yang diberikan, dimana pelayanan yang bermutu dapat diidentifikasi melalui kepuasan pengguna jasa, dalam penelitian ini 
adalah mahasiswa. Kepuasan adalah hasil dari pemenuhan konsumen bahwa pelayanan telah memberikan tingkat kenikmatan dimana tingkat pemenuhan ini bisa lebih atau kurang (Irawan, 2002:45). Untuk mencapai tingkat kepuasan yang tinggi, diperlukan adanya pemahaman apa yang diinginkan konsumen, dengan mengembangkan komitmen setiap orang yang ada dalam lembaga untuk memenuhi kebutuhan konsumen. Sehingga kepuasan mahasiswa terhadap kualitas pelayanan akademik juga menjadi salah satu faktor dimana mahasiswa merasa nyaman dalam menempuh pendidikan di suatu perguruan tinggi.

Di dalam pekerjaan teknis administrasi, layanan merupakan bagian dari aktivitas yang berupa mekanis. Layanan pada dasarnya adalah orang yang memberikan atau mengurus apa yang diperlukan oleh orang lain baik berupa barang atau jasa kepada pengguna jasa yang membutuhkan suatu informasi. Menurut Gronroos (dalam Ratminto dan Atik, 2009:2) mendefinisikan pelayanan adalah suatu aktivitas atau serangkaian aktivitas yang bersifat tidak kasat mata (tidak dapat diraba) yang terjadi akibat adanya interaksi antara konsumen dengan pegawai atau hal-hal lain yang disediakan oleh perusahaan pemberi pelayanan yang dimaksudkan untuk memecahkan permasalahan konsumen/pelanggan.

Layanan di sebuah administrasi berbeda dengan layanan pada kegiatan kemasyarakatan yang lain, seperti layanan kesehatan, layanan kependudukan dan layanan keagamaan. Perbedaan itu tentu dikaitkan dengan tugas dan fungsi masing-masing bidang, meskipun pada dasarnya suatu layanan mempunyai prinsip-prinsip yang sama atau berdekatan (Sutarno, 2006:189).

Pada prinsipnya konsep pelayanan memiliki berbagai macam definisi yang berbeda redaksi, namun pada intinya merujuk pada konsepsi dasar yang sama. Dan berikut ini diberikan beberapa definisi mengenai pengertian pelayanan.

1) Phillip Kotler (dalam Hendra Teguh, 2002:16) Pelayanan adalah kegiatan atau manfaat yang ditawarkan oleh suatu pihak pada pihak lain yang pada dasarnya tidak menghasilkan kepemilikan.

2) Moenir (2000:23) Pelayanan merupakan proses pemenuhan kebutuhan melalui aktivitas orang lain secara langsung. Pengertian 
proses ini terbatas dalam kegiatan manajemen untuk pencapaian tujuan organisasi.

3) Menurut Barata (dalam Erlando, 2004:2) Pelayanan adalah suatu kegiatan atau urutan kegiatan yang terjadi dalam interaksi langsung antara seseorang dengan orang lain atau mesin secara fisik, dan menyediakan kepuasan pelanggan.

4) Dalam Kamus Besar Bahasa Indonesia (1999:206) menyebutkan bahwa Pelayanan adalah membantu menyiapkan (mengurus) apa yang diperlukan seseorang.

5) Tjiptono (2005:31) Pelayanan adalah setiap tindakan atau perbuatan yang dapat ditawarkan oleh suatu pihak kepada pihak yang lain, yang pada dasarnya bersifat tidak berwujud fisik dan tidak menghasilkan kepemilikan apapun.

Bisnis jasa merupakan bisnis yang menjual layanan kepada para pengguna jasa yang membutuhkan. Berbeda dengan bisnis yang menjual barang, bisnis jasa menyediakan produk yang tidak berwujud dan tidak menyebabkan kepemilikan apapun bagi pengguna jasa yang menggunakannya. Jika bisnis produk atau barang dapat dimiliki pengguna barang setelah terjadi transaksi, bisnis jasa hanya bisa memberikan kualitas pelayanan yang diharapkan pengguna jasa setelah mereka melakukan transaksi walaupun tidak dapat memiliki pelayanan tersebut seterusnya.

Dalam memberikan kepuasan kepada pengguna jasa tidak terlepas dari sisi kualitas, baik kualitas produk atau jasa yang ditawarkan maupun dari segi layanan yang diberikan. Kualitas pelayanan akan dipengaruhi oleh beberapa faktor baik dari sisi internal (lembaga/Perguruan Tinggi) maupun eksternal (pelanggan/mahasiswa). Faktor internal tersebut antara lain kepuasan kerja pegawai, kompensasi yang diberikan, kemampuan menyesuaikan diri. "Kepuasan kerja tersebut meliputi kepuasan terhadap atasan, pekerjaan, bayaran/pengupahan, kesempatan berkembang, teman sekerja dan pengguna layanan" (Hartline \& fornell, 1996:17).

Kualitas layanan mencerminkan perbandingan antara tingkat layanan yang diberikan perusahaan dibandingkan dengan ekspektasi atau harapan pelanggan (Tjiptono, 2005). Faktor utama yang mempengaruhi kualitas layanan yaitu jasa yang diharapkan dan jasa yang dipersepsikan. Kualitas layanan 
diwujudkan melalui pemenuhan

kebutuhan dan keinginan pelanggan serta ketepatan penyampaiannya dalam mengimbangi atau melampaui harapan pelanggan. Semakin tinggi mutu pelayanan yang dilaksanakan, semakin banyak pula pelanggan yang terpuaskan. Produk merupakan segala sesuatu yang dapat ditawarkan produsen untuk diperhatikan, diminta, dicari, dibeli, digunakan (Suranto, 2009:95).Kualitas pelayanan merupakan penghubung terakhir dalam rantai aktivitas bagi sistem total quality management. Kualitas pelayanan juga merupakan sebuah unsur penting dari total quality untuk mempengaruhi keputusan (Chang, 1998:153).Banyak sebab mengapa pelayanan penyedia jasa tidak memuaskan pengguna jasa. Menurut Tjiptono (2001:51) dalam bukunya Manajemen Jasa mengemukakan bahwa gejala memburuknya kualitas pelayanan dapat terjadi apabila tuntutan dan permintaan pelanggan tidak dipenuhi, bahkan tidak tertanganinya permasalahan tersebut secara tepat dan cepat, dapat menyebabkan pelanggan berprasangka buruk dan sakit hati.

Philip Kotler (dalam Supranto, 2006:231) menjelaskan bahwa terdapat lima determinan kualitas pelayanan yang dapat dirincikan sebagai berikut :

1) Kepercayaan atau Kehandalan (Reliability): kemampuan untuk melaksanakan pelayanan yang djanjikan dengan tepat dan terpercaya.

2) Daya tanggap (Responsiveness): kemampuan untuk membantu pelanggan dan memberikan jasa dengan cepat atau ketanggapan.

3) Keyakinan (Assurance): pengetahuan atau kesopanan serta kemampuan pegawai untuk menimbulkan kepercayaan dan keyakinan.

4) Empati (Empaty): syarat untuk peduli, memberi perhatian pribadi bagi pelanggan.

5) Berwujud (Tangibles): penampilan fasilitas fisik, peralatan, personel dan media komunikasi.

Ukuran

keberhasilan

penyelenggaraan pelayanan di tentukan oleh tingkat kepuasan penerima pelayanan. Kepuasan penerima pelayanan dicapai apabila penerima pelayanan memperoleh pelayanan sesuai dengan yang dibutuhkan dan diharapkan.

Sehubungan dengan hal diatas untuk menilai pelayanan yang berkualitas maka dapat digunakan 
kriteria-kriteria atau faktor-faktor yang

dikemukakan oleh Zeithami (2004:48)

antara lain:

1) Responsiveness (daya tanggap) yaitu kemampuan untuk membantu dan memberikan pelayanan yang cepat (responsif) dan tepat kepada para pelanggan dengan Tangibles (bukti langsung), yaitu kemampuan suatu perusahaan dalam menunjukkan eksistensinya kepada pihak eksternal. Penampilan dan kemampuan sarana dan prasarana fisik perusahaan dan keadaan lingkungan sekitarnya adalah bukti nyata dari pelayanan yang diberikan perusahaan.

2) Reliability (kehandalan) yaitu kemampuan untuk memberikan pelayanan yang dijanjikan dengan segera, akurat dan memuaskan. Kinerja harus sesuai dengan harapan pelanggan yang berarti ketetapan waktu, pelayanan yang sama untuk semua pelanggan tanpa kesalahan, sikap simpatik dan akurasi yang tinggi.

3) Penyampaian informasi yang jelas. Membiarkan pelanggan menunggu tanpa adanya suatu alasan yang jelas menyebabkan persepsi yang negatif dalam kualitas pelayanan.
4) Assurance (jaminan), adanya kepastian yaitu pengetahuan, kesopan santunan dan kemampuan para pegawai perusahaan untuk menumbuhkan rasa percaya para pelanggan kepada pelayanan perusahaan yang memiliki:

a) Communication (komunikasi), yaitu secara terus menerus memberikan informasi kepada pelanggan dalam bahasa dan penggunaan kata yang jelas sehingga para pelanggan dapat dengan mudah mengerti di samping itu perusahaan hendaknya dapat secara cepat dan tanggap dalam menyikapi keluhan dan komplain yang dilakukan oleh pelanggan.

b) Credibility (kredibilitas), perlunya jaminan atas suatu kepercayaan yang diberikan kepada pelanggan, believability atau sifat kejujuran. Menanamkan kepercayaan, memberikan kredibilitas yang baik bagi perusahaan pada masa yang akan datang.

c) Security (keamanan), adanya suatu kepercayaan yang tinggi dari pelanggan akan pelayanan yang diterima. Tentunya pelayanan yang diberikan 
memberikan suatu jaminan kepercayaan yang maksimal

d) Competence (kompetensi) yaitu keterampilan yang dimiliki dan dibutuhkan agar dalam memberikan pelayanan kepada pelanggan dapat dilaksanakan dengan optimal.

e) Courtesy (sopan santun), dalam pelayanan adanya suatu nilai moral yang dimiliki oleh perusahaan dalam memberikan pelayanan kepada pelanggan. Jaminan akan kesopan santunan yang ditawarkan kepada pelanggan sesuai dengan kondisi dan situasi yang ada.

f) Empaty (empati) yaitu memberikan perhatian yang tulus dan bersifat individu atau pribadi yang diberikan kepada para pelanggan dengan berupaya memahami keinginan konsumen. Dimana suatu perusahaan diharapkan memiliki pengertian dan pengetahuan tentang pelanggan, memahami kebutuhan pelanggan secara spesifik, serta memiliki waktu pengoperasian yang nyaman bagi pelanggan.

Untuk mendapatkan gambaran mengenai definisi administrasi pendidikan/akademik, berikut ini adalah beberapa pendapat yang dikemukakan oleh para ahli :

a. Hadari Nawawi (dalam Daryanto, 2010:10) mengatakan administrasi akademik adalah rangkaian kegiatan atau keseluruhan proses pengendalian usaha kerjasama sejumlah orang untuk mencapai tujuan secara berencana dan sistematis yang diselenggarakan dalam lingkungan tertentu, terutama berupa lembaga pendidikan formal.

b. Engkoswara (dalam Daryanto, 2010:11) mengatakan administrasi pendidikan/akademik adalah ilmu yang mempelajari penataan sumber daya yaitu manusia, kurikulum atau sumber belajar secara optimal dan penciptaan suasana yang baik bagi manusia yang turut serta di dalam mencapai tujuan yang disepakati.

c. Ngalim Purwanto (2008:10) mengatakan administrasi akademik ialah segenap proses pengarahan dan pengintegrasian segala sesuatu, baik personel, spiritual dan material yang bersangkut paut dengan pencapaian tujuan akademik.

d. Kementerian Pendidikan Nasional (dalam Daryanto, 2010:12) mendefinisikan bahwa administrasi akademik adalah suatu proses, 
kegiatan bersama dalam akademik yang meliputi perencanaan, pengorganisasian, pengarahan, pengkoordinasian, pengawasan, pembiayaan, dan pelaporan dengan menggunakan atau memanfaatkan fasilitas yang tersedia, baik personel, material, maupun spiritual untuk mencapai tujuan akademik secara efektif dan efisien.

Untuk mendapatkan gambaran mengenai konsep kepuasan, berikut diberikan beberapa definisi para ahli :

1) Tjiptono dan Chandra (dalam Zulhan Yamit, 2001:55) mendefinisikan kepuasan sebagai upaya pemenuhan sesuatu atau membuat sesuatu memadai.

2) Biong (dalam Zulhan Yamit, 2001:56) menjelaskan bahwa kepuasan sebagai sebuah konsekuensi atau akibat atas pengalaman satu pihak terhadap kemampuan pihak lain untuk memenuhi norma-norma atau aturanaturan dengan harapan-harapannya.

3) Kepuasan didefinisikan Muhmin (dalam Zulhan Yamit, 2001:57) sebagai sebuah keadaan kasih sayang yang positif dihasilkan dari penilaian perusahaan terhadap seluruh aspek dari hubungan bekerjanya dengan perusahaan lain.
Hasil kepuasan pelanggan disebut juga dengan mutu, karena mutu dapat didefinisikan sebagai sesuatu yang memuaskan dan melampaui keinginan dan kebutuhan pelanggan. Mutu ini bisa disebut sebagai mutu yang hanya ada di mata orang yang melihatnya. Ini merupakan definisi yang sangat penting. Sebab, ada satu resiko yang sering sekali kita abaikan dari definisi ini, yaitu kenyataan bahwa para pelanggan adalah pihak yang membuat keputusan terhadap mutu. Dan mereka melakukan penilaian tersebut dengan merujuk pada produk terbaik yang bisa bertahan dalam persaingan. Kepuasan karyawan akan mendorong tumbuhnya loyalitas karyawan pada organisasi. Selanjutnya loyalitas karyawan akan mengarah pada peningkatan produktifitas. Produktifitas karyawan mendorong penciptaan nilai pelayanan eksternal yang kemudian menentukan kepuasan pelanggan eksternal, karena kepuasan pelanggan merupakan salah satu faktor penentu loyalitas pelanggan (Fandy Tjiptono, 2005:125).

Dalam era kompetisi bisnis yang ketat seperti sekarang, kepuasan pelanggan merupakan hal yang utama, pelanggan diibaratkan seorang raja yang harus dilayani namun hal ini bukan berarti menyerahkan segalanya kepada 
pelanggan. Usaha memuaskan kebutuhan

pelanggan harus dilakukan secara menguntungkan atau bersifat win-win solution yaitu keadaan dimana kedua belah pihak merasa menang dan tidak ada yang dirugikan (Mina Rahmayanti, 2010:6)

Patton (2000:12) menyatakan faktor kepuasan pelanggan dapat dilihat dari terpenuhinya lima komponen layanan sepenuh hati yaitu:

a. Memahami emosi-emosi kita,

b. Kompetensi,

c. Mengelola emosi-emosi kita,

d. Bersikap kreatif dan memotivasi diri sendiri,

e. Menyelaraskan emosi-emosi orang lain.

\section{METODE PENELITIAN}

\section{Populasi}

Jadi populasi dalam penelitian ini adalah seluruh mahasiswa Universitas Banten Jaya (UNBAJA) yang aktif terdaftar sebagai mahasiswa pada tahun ajaran 20162017, dengan rincian sebagai berikut

Tabel 1

Jumlah Mahasiswa UNBAJA

Tahun Ajaran 2016-2017

\begin{tabular}{llll}
\hline No. & FAKULTAS & $\begin{array}{l}\text { PROGRAM } \\
\text { STUDI }\end{array}$ & $\begin{array}{l}\text { JML } \\
\text { MAHAS } \\
\text { ISWA }\end{array}$ \\
\hline 1. & $\begin{array}{l}\text { Fakultas } \\
\text { Ilmu }\end{array}$ & $\begin{array}{l}\text { Sistem } \\
\text { Informatika }\end{array}$ & 204 \\
& Komputer & (S1) &
\end{tabular}

Teknik
2.

3.

5.

6.

7. Fakultas
Teknik

8.

9.

10. Keguruan Dan Ilmu Pendidikan

11.

TOTAL
Sumber: Bagian Akademik
UNBAJA

383 (S1)

Teknik

Informatika 50

(D3)

Manajemen Informatika 13

(D3)

Komputer

Akuntansi 12

(D3)

Teknik Sipil

(S1)

Teknik

Lingkungan 47

(S1)

Teknik Industri (S1) 366

Pend Bahasa Inggris (S1) 136

Pend

Kewarganegar 97 aan (S1)

Pend

Akuntansi $\quad 87$

1649

\section{Sampel}

Menurut Suharsimi Arikunto (2006:108) sampel adalah sebagian atau wakil populasi yang diteliti. Kemudian menurut Istijanto (2005:109) sampel adalah satu bagian yang ditarik dari populasi. Dan menurut Sutrisno Hadi (2004:182) sampel adalah sejumlah penduduk yang jumlahnya kurang dari jumlah populasi.

Teknik pengambilam sampel dari populasi dalam penelitian ini menggunakan Rumus Slovin (dalam Riduwan 2008:65), sebagai berikut : 
$n=\frac{\mathrm{N}}{\mathrm{N}(d)^{2}+1}$

$n=\frac{1.649}{1.649(0,05)^{2}+1}$

$n=\frac{1.649}{5,1225}$

$n=321,91$ dibulatkan menjadi 322

dimana :

$\mathrm{n}$ : Sampel

$\mathrm{N}$ : Populasi

d : Batas toleransi kesalahan (toleransi yang digunakan dalam penelitian ini adalah $5 \%=0,05)$.

\section{Teknik Pengumpulan Data}

Dalam melakukan penelitian ini teknik pengumpulan data yang peneliti lakukan adalah sebagai berikut :

a. Wawancara (Interview)

"Wawancara (Interview) digunakan sebagai teknik pengumpulan data, apabila peneliti ingin melakukan studi pendahuluan untuk menemukan permasalahan yang harus diteliti, dan juga peneliti ingin mengetahui hal-hal dari responden yang lebih mendalam dan jumlah respondennya sedikit/kecil”. (Sugiyono, 2008:194).

\section{b. Angket (Kuesioner)}

Kuesioner merupakan teknik pengumpulan data yang dilakukan dengan cara memberi seperangkat pertanyaan atau pernyataan tertulis kepada responden untuk dijawabnya (Sugiyono, 2008:199). Jenis kuesioner yang dipakai di dalam penelitian ini adalah kuesioner langsung dan tak langsung. Kuesioner langsung yaitu "daftar pertanyaan yang diajukan kepada seseorang untuk meminta keterangan kepada dirinya sendiri”. Sedangkan, kuesioner tak langsung adalah "daftar pertanyaan yang ditujukan kepada seseorang untuk meminta keterangan untuk orang lain". Maka dalam penelitian ini kuesioner diajukan kepada mahasiswa UNBAJA untuk mengetahui sejauh mana pengaruh pelayanan akademik terhadap tingkat kepuasan mahasiswa UNBAJA. Pertanyaan-pertanyaan yang dibuat dalam bentuk angket dengan menggunakan Skala Likert $1-5$ untuk mendapatkan data yang bersifat interval. Contoh untuk kategori pernyataan dengan jawaban sangat tidak setuju sampai dengan sangat setuju : 
Tabel 2

Skor Penilaian Kuesioner

\begin{tabular}{clc}
\hline No. & Kategori Jawaban & $\begin{array}{c}\text { Skor } \\
\text { item }\end{array}$ \\
\hline 1. & Sangat Setuju (SS) & 5 \\
2. & Setuju (S) & 4 \\
3. & Netral (N) & 3 \\
4. & Tidak Setuju (TS) & 2 \\
5. & Sangat Tidak Setuju & 1 \\
\hline
\end{tabular}

c. Observasi (Pengamatan)

Menurut S.Margono (2008:67)

observasi adalah "Pengamatan dan pencatatan secara sistematik terhadap gejala yang tampak pada objek penelitian. Berdasarkan pendapat diatas dapat dijelaskan bahwa observasi adalah melaksanakan pengamatan kepada objek yang akan diselidiki dengan sistematis. Metode ini digunakan sebagai penunjang untuk mengamati dan mengadakan pencatatan tentang pelayanan dan tingkat kepuasan mahasiswa.

\section{HASIL PENELITIAN DAN}

\section{PEMBAHASAN}

\section{Analisis Data}

Perhitungan untuk mengetahui seberapa tinggi kualitas pelayanan yang diberikan oleh staf akademik kepada mahasiswa :

$$
p=\frac{20.056}{322} \times 100 \%
$$

$p=62,28 \%$

Perhitungan selanjutnya dilakukan untuk mengetahui seberapa tinggi tingkat kepuasan mahasiswa terhadap pelayanan akademik yang telah diterima :

$$
\begin{aligned}
& x 1=\frac{20.056}{322}=62,28 \\
& y 1=\frac{24.619}{322}=76,45
\end{aligned}
$$

Kemudian hasil dari $\mathrm{x} 1$ dan y1 yang sudah diketahui diaplikasikan kedalam rumus :

$$
\begin{aligned}
& H a s i l=\frac{62,28}{76,45} \\
& \text { Hasil }=0,81
\end{aligned}
$$

\section{Uji Validitas}

Pengujian validitas menggunakan program aplikasiSPSS dengan metode Pearson Correlation, yaitu mengkorelasikan tiap item dengan skor total item kuisioner.

Keputusan untuk validitas:

(Alhusin, 2003:36)

- Jika $\mathrm{r}_{\text {hitung }}>\mathrm{r}_{\text {tabel }}$, maka item pertanyaan dinyatakan valid

- Jika $r_{\text {hitung }}<r_{\text {tabel }}$ atau $r$ hitung negatif, maka item pertanyaan dinyatakan tidak valid. 
Nilai $r$ tabel dapat dilihat pada table statistik $\mathrm{r}$ dengan $\mathrm{n}=322$ atau $\mathrm{df}=\mathrm{n}-2$ $=320$ dan dengan signifikansi 0,05 maka didapat nilai $r$ tabel $=0,109$. Dapat diketahui bahwa untuk variabel $\mathrm{X}$ dan $\mathrm{Y}$ semua item pertanyaan nilai Pearson Correlation lebih dari $\mathrm{r}$ tabel 0,109. Jadi dapat disimpulkan bahwa item-item pada kuesioner untuk variabel tersebut telah valid.

\section{Uji Reliabilitas}

Uji reliabilitas merupakan ukuran kestabilan dan konsistensi responden dalam menjawab hal yang berkaitan dengan pernyataan yang merupakan dimensi suatu variabel dan disusun dalam bentuk kuesioner.Metode pengujian reliabilitas yang digunakan pada penelitian ini adalah Cronbach's Alpha.

Pengambilan keputusan untuk uji reliabilitas adalah sebagai berikut :

- Cronbach's alpha $<0,60=$ reliabilitas buruk

- Cronbach's alpha 0,60 - 0,79= reliabilitas diterima

Dapat diketahui nilai Cronbach Alpha untuk variabel $\mathrm{X}$ dan $\mathrm{Y}$ di atas 0,600. Karena nilai diatas 0,600 jadi dapat disimpulkan bahwa alat ukur pada kuesioner telah reliabel.

\section{Uji Normalitas Residual}

Uji normalitas pada model regresi digunakan untuk menguji apakah nilai residual terdistribusi secara normal atau tidak. Model regresi yang baik adalah yang memiliki nilai residual yang terdistribusi secara normal.Cara untuk mendeteksinya adalah dengan melihat penyebaran data pada sumber diagonal pada grafik Normal P-P Plot of regression standardized sebagai dasar pengambilan keputusannya. Jika menyebar sekitar garis dan mengikuti garis diagonal maka model regresi tersebut telah normal dan layak dipakai untuk memprediksi variabel bebas dan sebaliknya. Cara lain uji normalitas adalah dengan metode uji One Sample Kolmogorov Smirnov. Kriteria pengujiannya adalah sebagai berikut:

- Jika nilai Signifikansi (Asym Sig 2 tailed) > 0,05, maka data berdistribusi normal.

- Jika nilai Signifikansi (Asym Sig 2 tailed) $\leq 0,05$, maka data tidak berdistribusi normal.

\section{Uji Heteroskedastisitas}

\begin{tabular}{ccr}
\multicolumn{2}{c}{ Heteroskedastisitas } & adalah \\
keadaan & dimana & terjadi \\
ketidaksamaan & varian dari & residual
\end{tabular}


untuk semua pengamatan pada model regresi.Untuk mendeteksi ada tidaknya heteroskedastisitas dengan melihat pola titik-titik pada scatterplots regresi. Jika titik-titik menyebar dengan pola yang tidak jelas diatas dan dibawah angka 0 pada sumbu Y maka tidak terjadi masalah heteroskedastisitas.

Heteroskedastisitas adalah keadaan dimana terjadi ketidaksamaan dari residual untuk semua pengamatan pada model regresi.Untuk mendeteksi ada tidaknya heteroskedastisitas dengan melihat pola titik-titik pada scatterplots regresi.Jika titik-titik menyebar dengan pola yang tidak jelas diatas dan dibawah angka 0 pada sumbu Y maka tidak terjadi masalah heteroskedastisitas.Hasil uji heteroskedastisitas dapat diketahui bahwa variabel independen memiliki nilai signifikansi lebih dari 0,05, sehingga dapat disimpulkan tidak ada masalah heteroskedastisitas pada model regresi.

\section{Uji Linearitas}

Uji ini digunakan untuk melihat apakah terjadi hubungan yang linier atau tidak antar variabel. Uji yang digunakan adalah uji Mean-Test for Linearity menggunakan SPSS. Dua variable dikatakan mempunyai hubungan yang linear bila nilai signifikansi pada Linearity kurang dari 0,05, atau berdasar teori lain yaitu jika signifikansi pada Deviation From Linearity lebihdari 0,05 maka kedua variable berhubungan secara linier.

\section{Uji Hipotesis}

\section{Analisis Korelasi Product Moment}

Untuk mengetahui pengaruh antara variabel Pelayanan Akademik dan variabel Kepuasan Mahasiswa.

\section{Analisis Regresi Linear Sederhana}

Analisis regresi linier sederhana digunakan untuk mengetahui pengaruh variabel independen terhadap variabel dependen baik secara parsial (uji t) maupun secara bersama-sama (uji F). Persamaan regresi linear sederhana digunakan untuk merumuskan persamaan regresi dan untuk mengetahui nilai peningkatan atau penurunan variabel $\mathrm{Y}$ atas perubahan variabel $\mathrm{X}$.

Bentuk umum persamaan regresi linier sederhana yaitu sebagai berikut:

$$
\mathrm{Y}=\mathrm{a}+\mathrm{bX}
$$

Persamaan regresinya sebagai berikut:

$$
Y=45,489+0,497 X
$$




\section{Uji t}

Uji $t$ dalam regresi sederhana digunakan untuk mengetahui apakah model regresi variable independen secara parsial berpengaruh signifikan terhadap variable dependen.

Hipotesis:

- Ho: Tidak ada pengaruh $\mathrm{X}$ terhadap Y

- Ha: Ada pengaruh X terhadap Y

Kriteria pengambilan keputusan:

- Ho diterima bila $-\mathrm{t}$ hitung $\geq-\mathrm{t}$ tabel atau $\mathrm{t}$ hitung $\leq \mathrm{t}$ tabel (tidak berpengaruh)

- Ho ditolak bila $-\mathrm{t}_{\text {hitung }}<-\mathrm{t}_{\text {tabel }}$ atau $t_{\text {hitung }}>t_{\text {tabel }}$ (berpengaruh)

Catatan: Nilai $\mathrm{t}_{\text {table }}$ dapat dilihat pada tabel $\mathrm{t}$ statistik pada $\mathrm{df}=\mathrm{n}-\mathrm{k}-1$ atau 322-1-1 = $320 \quad(\mathrm{k}$ adalah jumlah variabel independen). Dengan signifikansi 0,05 , dan uji 2 sisi. Diperoleh hasil $\mathrm{t}_{\text {table }}=1,967 /-1,967$.

\section{Koefesien Determinasi}

Koefesien determinasi adalah ukuran yang menunjukkan seberapa besar variabel $\mathrm{X}$ memberikan kontribusi terhadap variabel $\mathrm{Y}$. Koefesien determinasi digunakan untuk mengetahui prosentase sumbangan pengaruh variabel independen secara serentak terhadap variabel dependen.

\section{Analisis Deskriptif}

Penelitian ini dilaksanakan di Universitas Banten Jaya pada bulan April 2017. Data dikumpulkan melalui 322 responden yang dalam penelitian ini yang menjadi responden adalah mahasiswa Universitas Banten Jaya. Berdasarkan analisis deskripsi terhadap data-data penelitian menggunakan program aplikasiSPSS (Statistical Program for Social Science) for Windows Releasev versi 22.

\section{Pembahasan}

Penelitian ini menggunakan bantuan program aplikasiSPSS (Statistical Program for Social Science) for Windows Releaseversi 22. Dari penelitian yang telah dilakukan dengan menyebarkan kuesioner kepada 322 responden maka dapat diketahui seberapa besar pengaruh Pelayanan Akademik terhadap Tingkat Kepuasan Mahasiswa Universitas Banten Jaya (UNBAJA).

Dari hasil analisis data yang telah dilakukan dapat diketahui bahwa hasil penelitian ini menunjukkan adanya pengaruh yang signifikan antara variabel pelayanan akademik terhadap tingkat kepuasan mahasiswa Universitas Banten Jaya (UNBAJA). Hal ini dibuktikan dari hasil perhitungan analisis data statistik 
yang telah dilakukan dan diperoleh hasil demikian.

Diketahui hasil dari prosentase kualitas pelayanan akademik yang diambil berdasarkan dari jawaban responden sebesar $62,28 \%$ yang menunjukkan bahwa kualitas pelayanan akademik Universitas Banten Jaya (UNBAJA) termasuk kedalam kategori

\section{"Kualitas Pelayanan Tinggi".}

Diketahui hasil dari kepuasan mahasiswa yang diperoleh dari perhitungan diatas sebesar 0,81 dimana hasil ini menunjukkan bahwa kepuasan mahasiswa terhadap pelayanan akademik Universitas Banten Jaya (UNBAJA) termasuk kedalam kategori "Puas".

Dari hasil output diperoleh harga koefesien korelasi sebesar 0,678 dengan nilai signifikansi yang dimiliki oleh Pelayanan Akademik sebesar 0,000. Berdasarkan data tersebut diatas maka dapat dilakukan pengujian hipotesis dengan membandingkan taraf signifikansi (p-value).

- Jika signifikansi > 0,05, maka Ho di terima

- Jika signifikansi < 0,05, maka Ho di tolak

Pada kasus ini terlihat bahwa koefesien korelasi adalah 0,678 dengan signifikansi 0,000 . Karena signifikansi
$<0,05$ maka Ho di tolak berarti $\mathrm{Ha}$ di terima. Artinya ada pengaruh yang signifikan antara Pelayanan Akademik terhadap Tingkat Kepuasan Mahasiswa Universitas Banten Jaya (UNBAJA).

Apakah koefesien korelasi hasil analisis korelasi product moment tersebut $\mathrm{r}_{\text {tabel}}$, pengujiannya adalah sebagai berikut:

- Jika $r_{\text {hitung }}>\mathrm{r}_{\text {tabel, }}$, maka Ho di tolak

- Jika $\mathrm{r}_{\text {hitung }}<\mathrm{r}$ tabel, maka Ho di terima

Dengan taraf kepercayaan 5\% maka dapat diperoleh harga $r$ tabel 0,181 . Ternyata $r$ hitung lebih besar dari $r$ tabel $(0,678>0,0181)$, sehingga Ho di tolak dan Ha di terima, yang artinya Pelayanan Akademik mempunyai pengaruh yang signifikan dengan Tingkat Kepuasan Mahasiswa. Berdasarkan hasil koefesien korelasi tersebut juga dapat dipahami bahwa korelasinya bersifat positif, artinya semakin tinggi tingkat kualitas pelayanan akademik maka akan dibarengi dengan semakin tinggi pula tingkat kepuasan mahasiswa. Dengan memperhatikan harga koefesien korelasinya sebesar 0,678 berarti korelasinya bersifat kuat.

Berdasarkan hasil output pada analisis perhitungan uji t diatas maka dapat disimpulkan bahwa variabel 
pelayanan akademik berpengaruh terhadap kepuasan mahasiswa. Hal ini karena nilai $\mathrm{t}$ hitung > $\mathrm{t}$ table $(8,516>$ $1,967)$ atau signifikansi $<0,05(0,000<$ 0,05) sehingga Ho ditolak. Pengaruhnya positif karena nilai $t$ hitung positif, artinya jika pelayanaan akademik meningkat maka kepuasan mahasiswa juga meningkat.

Berdasarkan hasil output yang diperoleh dari perhitungan koefesien determinasi menunjukkan bahwa variabel pelayanan akademik memiliki sumbangan pengaruh terhadap kepuasan mahasiswa sebesar 0,560 atau $56 \%$ dan sisa nya dipengaruhi faktor lain yang tidak diteliti.

Dilihat dari hasil analisis frekuensi jawab tiap item dapat disimpulkan sebagai berikut,

1. Pertanyaan ke-1 sebanyak $44.4 \%$ responden menjawab tidak setuju, dan dapat di artikan bahwa sarana dan prasarana pembelajaran masih belum cukup memadai.

2. Pertanyaan ke-2 sebanyak $40.4 \%$ responden menjawab tidak setuju, dan dapat di artikan bahwa kapasitas kelas masih belum ideal dengan jumlah mahasiswa yang ada.

3. Pertanyaan ke-3 sebanyak $86.9 \%$ dari jawaban akumulasi responden yang menjawab netral, setuju dan sangat setuju, dan dapat di artikan bahwa tingkat kehadiran dosen untuk memberikan materi sudah cukup baik.

4. Pertanyaan ke-4 sebanyak $43.2 \%$ responden menjawab tidak setuju, dan dapat di artikan bahwa tingkat keterlambatan dosen masih tinggi.

5. Pertanyaan ke-5 sebanyak $92 \%$ dari jawaban akumulasi responden yang menjawab netral, setuju dan sangat setuju, dan dapat diartikan bahwa sebagian mahasiswa telah memahami materi yang diberikan dengan baik.

6. Pertanyaan ke-6 sebanyak $33.9 \%$ responden menjawab tidak setuju, dan dapat di artikan bahwa bahan ajar yang diberikan dosen masih belum cukup untuk mahasiswa.

7. Pertanyaan ke-7 sebanyak $32.6 \%$ responden menjawab tidak setuju, dan dapat di artikan bahwa tingkat kepedulian dosen terhadap mahasiswa masih lebih dibutuhkan.

8. Pertanyaan ke-8 sebanyak $34.8 \%$ responden menjawab tidak setuju, dan dapat di artikan bahwa menurut mahasiswa keberadaan ASDOS (assistant dosen) masih belum memadai untuk menggantikan dosen yang berhalangan hadir.

9. Pertanyaan ke-9 sebanyak $80.8 \%$ dari jawaban akumulasi responden 
yang menjawab netral, setuju dan sangat setuju, dan dapat di artikan bahwa staff akademik selalu ada ditempat.

10. Pertanyaan ke-10 sebanyak $90.4 \%$ dari jawaban akumulasi responden yang menjawab netral, setuju dan sangat setuju, dan dapat di artikan bahwa staff akademik memiliki kemampuan yang cepat tanggap dalam melayani mahasiswa.

11. Pertanyaan ke-11 sebanyak 77.3\%dari jawaban akumulasi responden yang menjawab netral, setuju dan sangat setuju, dan dapat di artikan bahwa staff akademik santun dalam memberikan pelayanan.

12. Pertanyaan ke-12 sebanyak 84.2\%dari jawaban akumulasi responden yang menjawab netral, setuju dan sangat setuju, dan dapat di artikan bahwa staff akademik selalu memberikan informasi yang dibutuhkan mahasiswa.

13. Pertanyaan ke-13 sebanyak 86.7\%dari jawaban akumulasi responden yang menjawab netral, setuju dan sangat setuju, dan dapat di artikan bahwa staff akademik selalu berusaha membantu mahasiswa.

14. Pertanyaan ke-14 sebanyak $37.6 \%$ responden menjawab setuju, dan dapat di artikan bahwa fasilitas laboratorium komputer sudah cukup nyaman dan memadai.

15. Pertanyaan ke-15 sebanyak 90.1\%dari jawaban akumulasi responden yang menjawab netral, setuju dan sangat setuju, dan dapat di artikan bahwa ruang perpustakaan sudah cukup nyaman dan memiliki koleksi buku-buku yang cukup lengkap.

16. Pertanyaan ke-16 sebanyak $36.3 \%$ responden menjawab tidak setuju, dan dapat di artikan bahwa pelayanan administrasi pada sistem komputerisasi masih belum membuat mahasiswa nyaman menggunakannya.

17. Pertanyaan ke-17 sebanyak $53.7 \%$ responden menjawab setuju, dan dapat di artikan bahwa fasilitas ibadah dan ketersediaan kamar kecil sudah cukup memadai.

18. Pertanyaan ke-18 sebanyak $41.0 \%$ responden menjawab tidak setuju, dan dapat di artikan bahwa sebagian mahasiswa masih kurang memahami dalam sistem pengurusan pendaftaran KRS.

19. Pertanyaan ke-19 sebanyak $71.4 \%$ responden menjawab sangat tidak setuju, dan dapat di artikan bahwa fasilitas jaringan internet yang 
disediakan belum cukup untuk memenuhi kebutuhan mahasiswa.

20. Pertanyaan ke-20 sebanyak $50.0 \%$ responden menjawab setuju, dan dapat di artikan bahwa fasilitas tempat parkir kendaraan mahasiswa sudah cukup memadai dan aman.

\section{KESIMPULAN DAN SARAN}

Berdasarkan uraian dan hasil pembahasan pada penelitian dalam skripsi ini yang telah dikemukakan pada bab-bab terdahulu, maka dapat diambil kesimpulan sebagai berikut :

1. Berdasarkan hasil dari perhitungan prosentase kualitas pelayanan akademik yang diambil berdasarkan dari jawaban responden sebesar $62,28 \%$ yang menunjukkan bahwa kualitas pelayanan akademik Universitas Banten Jaya (UNBAJA) termasuk kedalam kategori "Kualitas Pelayanan Tinggi".

2. Dilihat dari hasilperhitungan kepuasan mahasiswa yang memperoleh nilai sebesar 0,81 dimana hasil ini menunjukkan bahwa kepuasan mahasiswa terhadap pelayanan akademik Universitas Banten Jaya (UNBAJA) termasuk kedalam kategori "Puas".

3. Dari harga koefesien korelasi yang diperoleh sebesar 0,678 yang memiliki arti bahwa pengaruh Pelayanan Akademik (X) terhadap Tingkat Kepuasan Mahasiswa (Y) adalah sebesar $67,8 \%$ dan sisanya sebesar $32,2 \%$ dipengaruhi oleh variabel lain yang tidak diteliti. Dengan signifikansi 0,000. Karena signifikansi $<0,05$ maka Ho di tolak berarti $\mathrm{Ha}$ di terima. Pada uji $\mathrm{t}$ diketahui nilai t hitung sebesar 8,516 dan $t_{\text {tabel }}$ sebesar 1,967. Dimana hasil hipotesis statistik menerangkan bahwa Ho ditolak dan Ha diterima. Dengan demikian dapat disimpulkan bahwa ada pengaruh yang signifikan antara Pelayanan Akademik terhadap Tingkat Kepuasan Mahasiswa Universitas Banten Jaya (UNBAJA).

Berdasarkan kesimpulan diatas, maka dapat dikemukakan beberapa saran yang kiranya dapat bermanfaat bagi Akademik Universitas Banten Jaya (UNBAJA), yaitu :

1. Hendaknya kualitas pelayanan akademik Universitas Banten Jaya (UNBAJA) dapat dipertahankan seperti kondisi sekarang ini yang menurut hasil dalam penelitian ini ada dalam kategori kualitas pelayangan tinggi, dan akan lebih baik dan sangat diharapkan jika kualitas pelayanan dapat ditingkatkan lagi dari yang sebelumnya, sehingga 
dapat menciptakan nilai kepuasan mahasiswa yang lebih tinggi lagi.

2. Hendaknya segala fasilitas sarana dan prasarana yang dianggap oleh para mahasiswa masih belum cukup memadai untuk lebih di tindak lanjuti, supaya harapan mahasiswa dapat sebanding dengan pelayanan yang diberikan.

\section{DAFTAR PUSTAKA}

Alhusin, Syahri (2003) Aplikasi Statistik Praktis dengan Menggunakan SPSS 10 for Windows. Edisi Kedua.Yogyakarta: Graha Ilmu.

Arikunto, Suharsimi. ( 2006). Prosedur Penelitian: Suatu Pendekatan Praktis. Jakarta: PT. Bina Aksara

Chang Zeph Yun, et. aI.(1998). Kualitas Global Manajemen Kualitas Total (TQM) di Singapura Airlines (SIA). Jakarta: Pustaka Delapratasa.

Daryanto, M.(2010). Administrasi Pendidikan. Jakarta: Rineka Cipta

Erlando.( 2004). Analisis Pengaruh Pelayanan Prima (Service Excellence) Terhadap Kepuasan Pelanggan. Jakarta: Balai Pustaka

Hadi, Sutrisno. ( 2004). Statistik Jilid 3. Yogyakarta: Andi

Hartline Michael D \& Fornell.( 1996). Journal of Marketing Science. Jakarta: Balai Pustaka
Hendra Teguh, et.al. (2002). Pelayanan Administrasi Akademik. Bandung: PT.Remaja Rosdakarya

Irawan, Ho.(2002). 10 Prinsip Kepuasan Pelanggan. Jakana: PT. Elex Media Komputindo Gramedia

Istijanto (2005). Riset Sumber DayaManusia, Cetakan Kedua. Jakarta: PT.Gramedia Pustaka Utama

Margono, S. ( 2008). Metodologi Penelitian Pendidikan. Jakarta: Rineka Cipta

Moenir.( 2000). Analisis Kinerja Pelayanan Importasi Jalur Hijau pada Kantor Wilayah VI Direktorat Jenderal Bea dan Cukai Semarang. Semarang: Badan Penerbit UNDIP

Patton, Patricia (2000). EQ Pelayanan Sepenuh Hati. Jakarta: Pustaka Delapratasa

Purwanto, Ngalim .(2008). Administrasi Dan Supervisi Pendidikan. Bandung: PT. Remaja Rosdakarya

Rahmayanti, Mina.( 2010). Manajemen Pelayanan Prima. Yogyakarta: Graha Ilmu

Sugiyono dan Agus Susanto.(2015). Cara Mudah Belajar SPSS \& Lisrel. Bandung: Alfabeta

Sugiyono.( 2008). Metode Penelitian Bisnis. Bandung : Alfabeta

Supranto, J.( I 999). Pengukuran variabel kepuasan pelanggan. Jakarta: PT. Rineka Cipta -.(2006). Pengukuran Tingkat Kepuasan Pelanggan. Jakarta: PT. Rineka Cipta 
Suranto.( 2009). Manajemen Mutu

Dalam Pendidikan. Semarang:

CV. Ghyas Putra

Sutarno, NS( 2006). Manajemen

Perpustakaan "Suatu Pendekatan

Praktik'.Jakarta: CV. Sagung Seto

Tjiptono,Fandy. (2005). Prinsip-prinsip

Total Quality Service.

Yogyakarta: Andi

,Fandy.(2001). Manajemen Jasa.

Yogyakarta: Andi.

Valarei, Zeitharri. (2004) . Service

arketing. J akarta: Integrating

Customer

Winarsih, Atik Septi\& Ratminto. (2009).

Manajemen Pelayanan.

Yogyakarta:Pustaka Pelajar

Yamit, Zulhan.( 2001). Manajemen

Kualitas Produk dan Jasa.

Yogyakarta: Ekonisa 